\title{
Augmenting the Urban Place Brand - On the relationship between markets and town and city centres
}

\author{
Andrew Alexander, Christoph Teller \& Steve Wood
}

(published in the Journal of Business Research in 2019)

\begin{abstract}
Andrew Alexander, Department of Marketing and Retail Management (Surrey Business School), University of Surrey, Guildford, GU2 7XH, UK (a.alexander@surrey.ac.uk tel. +44 1483 689665).

Christoph Teller (corresponding author), Department of Marketing and Retail Management (Surrey Business School), University of Surrey, Guildford, GU2 7XH, UK (c.teller@surrey.ac.uk tel. +44 1483 683981).

Steve Wood, Department of Marketing and Retail Management (Surrey Business School), University of Surrey, Guildford, GU2 7XH, UK (sm.wood@surrey.ac.uk tel. +44 148368 3113).

*Corresponding author: Christoph Teller
\end{abstract}

\section{Acknowledgements:}

Authors are presented in alphabetical order. All authors contributed equally to the research presented in this paper. We wish to acknowledge Laura Seifert and Tobias Trattner for their help in the collection and initial analysis of the data. We also acknowledge the helpful suggestions of the reviewers on earlier versions of this paper.

\section{Biographies of Authors:}

Andrew Alexander is Professor of Retail Management at Surrey Business School, University of Surrey. His areas of research expertise include the long-term development of retail systems, the practice of retail management and the marketing and management of town centres.

Christoph Teller is Professor of Retailing and Marketing and Head of the Department of Marketing and Retail Management at Surrey Business School, University of Surrey. His research interests are in the areas of store (format) and agglomeration (format) patronage, retail operations and supply chain partnering.

Steve Wood is Professor of Retail Marketing and Management and Director of Research at Surrey Business School, University of Surrey. He has held previous positions at University of Southampton, in the marketing department of Tesco plc and in retail analysis at Verdict Research. Steve researches issues relating to retail management, economic geography and retail marketing.

Please cite as: Alexander, Andrew, Teller, Christoph, Wood, Steve. 2019. Augmenting the Urban Place Brand - On the relationship between markets and town and city centres. Journal of Business Research. DOI: 10.1016/j.jbusres.2019.02.013. 


\title{
Augmenting the Urban Place Brand - On the relationship between markets and town and city centres
}

\begin{abstract}
This paper explores (1) the interrelationship between the commercial performance of markets and town and city centres, (2) the positive and negative spill-over effects between them and (3) the implications for the understanding of the place brand and its management. It employs a network and place branding perspective and applies a multi-method case study approach utilising surveys and semi-structured interviews with stall-, store- and city centre managers in two European cities. Results reveal strong relationships between the commercial performance of the markets and the performance of the city centres. Findings confirm bi-directional positive spill-over effects between markets and city centres. Further, they reveal negative spill-over effects related to infrastructural deficiencies of the city centres and negative by-products of the increased footfall generated by the markets. This research provides insights into the role of markets as key features of urban place products and their potential in augmenting an urban place brand.
\end{abstract}

\section{Keywords:}

Place branding, place management, place marketing, spill-over, markets, town/city centres, retail agglomerations;

\section{Highlights:}

- The commercial performance of a market and the city centre are strongly interrelated.

- Positive and negative spill-over effects exist between markets and city centres.

- This research shows:

$\circ$ The role of markets as key features of urban place products and

○ Their potential in augmenting an urban place brand. 


\section{Graphical Abstract}

\section{The Role of Place Management in Influencing Spill-over Effects between Markets and Town/City Centres for the Benefit of the Place Brand}

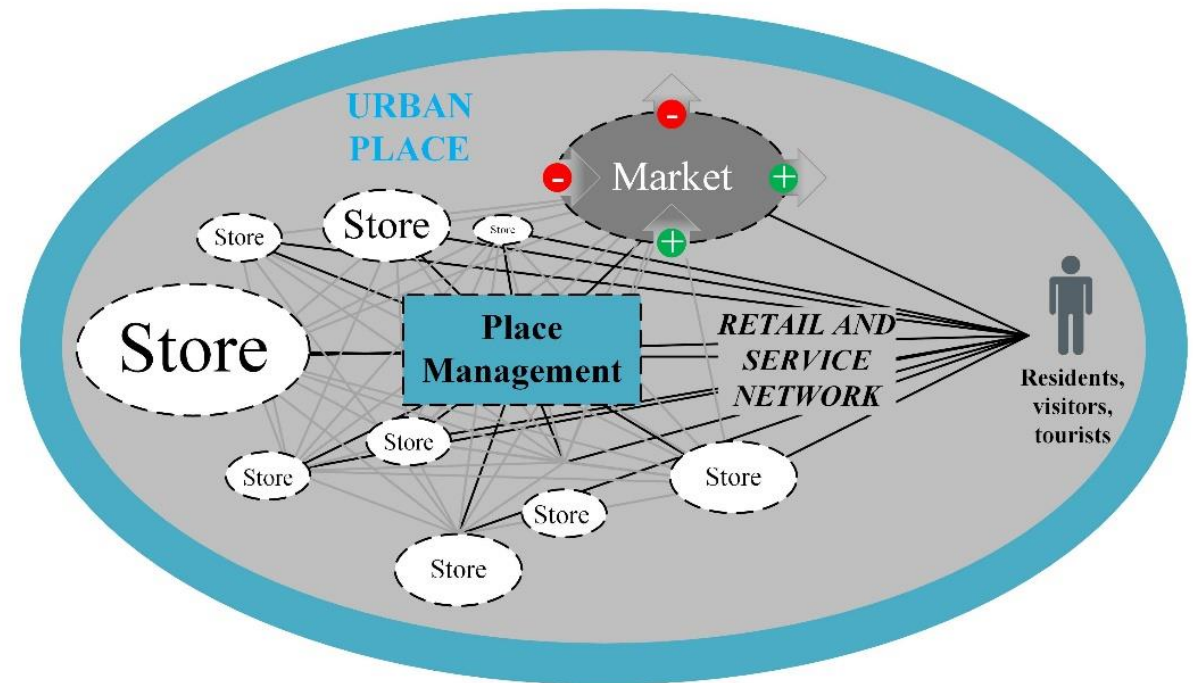

Potential Spill-over Effects from Market to Town/City Centre

$+$

Positive spill-over effect

+ Increased footfall/vitalisation of town/city centre

+ Increased booking of overnight stays

+ Increased willingness to spend/consume by customers

+ Higher customer retention time

+ Increased attractiveness of the retail and service network (retail/service offer, atmosphere, shopping experience)

+ Increased social interaction between and within place user/stakeholder groups

+ Medium to promote the town/city and region
- Negative spill-over effect

- Strain on infrastructure at peak times (traffic, parking, footpaths, waste disposal, street cleaning) - Competition for existing businesses - creation of secondary, disadvantaged shopping locations - Avoidance of town/city centre by local patrons due to crowding

- Disturbance of residents because of increased noise - Safety and security issues due to crowding, and crime

\section{Potential Spill-over Effects from Town/City Centre to Market}

\section{Positive spill-over effect}

+ Existing catchment

(and related footfall)

+ Established accessibility with car and public transport

+ Good infrastructure - traffic, parking amenities, high quality hospitality and retail service sector, wide and complementary retail and service offer

+ Good reputation with tourists and shoppers

+ Attractive environment

+ Unique historic and cultural setting

\section{Negative spill-over effect}

- Strained traffic and parking infrastructure (at peak times)

- Missing infrastructural services e.g. parking guidance system, pedestrian orientation system and signage, wireless LAN

- Market becomes focus for undesirable behaviour 


\section{Augmenting the Urban Place Brand - On the relationship between markets and town and city centres}

\section{Introduction}

Retailing in town and city centres has experienced competitive forces from decentralised retail and service agglomerations, such as shopping malls, and more recently from online channels (Jones and Livingstone, 2018). This competition has led to a decrease in the attractiveness of town and city centres as shopping destinations for customers (Wrigley and Lambiri, 2014). More widely, such centres are at risk of losing, or at least seeing a lessening of their traditional function - as a place where various place user groups (e.g. residents, business owners, visitors and tourists), trade, consume and meet (Powe and Hart, 2008). Hence, the question as to what can enhance the brand of a town or city, in terms of customer experience, has become increasingly important for town and city managers (Hart et al., 2013).

In this study, we explore the nature of the interdependence between markets and town/city centres to assess the implications for the latter as a place brand. Empirically we focus on Christmas markets, an increasingly present and commercially potent feature in urban environments. The research questions we seek to answer are: (1) How strong is the interrelationship between the commercial performance of markets and the town and city centres that host them? (2) What are the positive and negative spill-over effects between markets and the town and city centres? (3) What are the implications of such spill-over effects for our understanding of the place brand and its management? Our focus is primarily upon the commercial performance dimension, but extends beyond this to include related social impacts connected to residents and their communities. Importantly, our concern is with what Lucarelli and Berg have characterised as a perspective on the production of place brands - that is to say, a 'focus on how to produce, create, and manage a brand as well as how to organize and govern a branding process' (Lucarelli and Berg, 2011: 18) - rather than the management of the branding communication process itself (Kavaratzis and Hatch, 2013).

To effectively manage, market and brand an urban place it is vital to appreciate the distinctive features of that urban place brand relative to competitors and to focus on the views of various place user groups (Hospers, 2006). In the academic literature contributing to the place branding debate, there are concerns that practical processes of place branding are frequently conceived as "top down" procedures imposed on locales by professional branding managers (Hultman et 
al., 2016) rather than reflecting the necessary complexity of urban ecosystems (Zenker, 2011). This paper takes into account such complexity and presents a network view of urban place infrastructures and stakeholders, and of place branding (Hankinson, 2015). The network perspective provides a useful vehicle for investigating the relationship between network nodes (and their agents) of different kinds in order to understand the constituent elements of urban place brands, including how this can lead to differentiation and potential competitive advantage (Castéran and Roederer, 2013).

The contribution of this paper is to understand the interplay of a geographically-bounded retail and service network (the town or city centre) with a sub-network (the market) as an augmentation of a place product and brand. There is also an empirical contribution, for whilst there have been a number of attempts to generate holistic models of place brand management, there has been little empirical work (Hanna and Rowley, 2011) - and particularly a lack of quantitative research (Lucarelli and Berg, 2011). The practical contribution is to assist market and town/city managers to understand markets as a key place brand feature, and thus to better manage the benefits as well as challenges of markets in this regard.

Our empirical focus in this study is upon the role of Christmas markets - an agglomeration of non-permanent retail and service outlets - in augmenting existing town and city centre ecosystems. Christmas markets have been identified as important generators of retail turnover, and can provide a significant seasonal trading opportunity for some town and city centres that are competing for consumer spending (National Association of British Market Authorities, 2015). They represent an increasingly common phenomenon across Europe (Statista, 2014). We consider the Christmas market as a particular type of specialty market. The role of these markets in present-day Christmas festivities is heavily connected to consumption and closely associated with seasonal leisure and tourism activities (Haid, 2006). This helps to distinguish them from other types of market such as traditional, country and some other forms of specialty market. Clearly, experiential attributes are important with regard to Christmas markets. In particular, authenticity is widely identified as a significant element of the appeal of successful markets (Castéran and Roederer, 2013).

The structure of the remainder of the paper is as follows. In the next section, we explore the literature on place brands and branding, and that on networks - including the role of markets in urban environments - in order to provide a conceptual foundation to our research. We then 
present propositions that guide our research and the methodology underpinning our empirical study. Following the presentation of the results of two case study investigations, we provide a discussion of our findings with respect to the literature. Finally, we address the limitations of our research and suggest an outlook for further research.

\section{Literature Review}

\subsection{Place brands - Infrastructures and relationships}

Cresswell and Hoskins (2008: 394) note, 'place is anything but straightforward'. They argue that place simultaneously evokes a certain tangible materiality (encompassing the built and natural environments) alongside a less concrete meaning which comes together to produce a 'lived experience'. Similarly, Therkelsen et al. (2010) discuss this dualism in terms of a 'city of words', to denote the symbolic representation of place, with the 'city of stones' which refers to physical place-making. Warnaby and Medway (2013) contend that such distinctions are not mutually exclusive but are connected in many ways. For Kavaratzis and Kalandides (2015), place is perceived and constructed through a process of synthesizing 'materiality/physical elements, practices/structures of social interactions, regulating institutions and systems of representations' (p 1369). Kavaratzis and Hatch (2013) neatly summarise the thrust of this literature relating to the origins of place brand and identity which they view as 'formed through a complex system of interactions between the individuals and the collective, between the physical and the non-physical, between the functional and the emotional, between the internal and the external, and between the organized and the random' ( $p$ 76). The implications of such complexity is increasingly recognised with regard to the place branding process itself (Hankinson, 2015).

The activities that occur within a town or city, such as regular street markets, Christmas and other specialty markets, festivals and the like, can play a key role in place differentiation and serve to augment the core urban place "product" (Warnaby, 2013). Through such augmentation, markets represent part of the core place brand personality which comprises functional, symbolic and experiential attributes (Hankinson, 2004). Hankinson (2004: 116) argues that 'the ultimate success of a place branding strategy relies on the effective extension of the core brand through effective relationships with stakeholders, each of which extends and reinforces the reality of the core brand through consistent communication and delivery of services.' He presents four categories of relationships: (1) primary service relationships (e.g. those with retailers, event and leisure activity providers etc.); (2) brand infrastructure 
relationships (e.g. with transport services providers, providers of hygiene facilities such as car parks etc.); (3) consumer relationships; (4) media relationships.

Similarly, in presenting their Strategic Place Brand Management Model, Hanna and Rowley (2011) highlight the significance of 'brand infrastructure relationships and leadership', where such 'infrastructure' comprises tangible (functional) and intangible (experiential) elements. The former relate to the built environment, the landscape, urban design and public spaces, while the latter experiential attributes are comprised of symbolic traits such as cultural entertainment and services which combine with the functional attributes (Hanna and Rowley, 2011: 467). These notions of a multi-faceted place brand whose development is influenced by interactions resulting from a wider 'relational network' (Hankinson, 2004: 115) is highly appropriate in the case of markets that augment the existing town or city centre infrastructure on a temporary basis.

\subsection{Retail and service networks in urban places}

The relationships that facilitate and sustain the place brand occur through interactions between nodes (represented by agents) in a network. Retail and service network benefits have been explored in the literature from a variety of perspectives. Service Delivery Networks, for example, adopt an ego-net approach from the perspective of the customer (Tax et al., 2013: 457). Other research focuses more upon so-called strategic nets, which are intentionally created business networks (Möller and Rajala, 2007: 895). More particularly, research on shopping centres as networks offers useful insight, albeit with a concern to identify the effects between the wider network and individual nodes (firms' retail and service outlets) (for an overview see e.g. Teller et al., 2016b). In relation to shopping centre settings, retail tenants' perceptions that agglomeration or network effect drivers play a substantial role in influencing their success have been confirmed (Teller and Schnedlitz, 2012). Similarly, assessment of the attractiveness of agglomerations to customers shopping at them reveals the importance of the network's tenant mix, its atmosphere and ambience among other factors (Oppewal and Holyoake, 2004; Teller and Reutterer, 2008). From a retail management perspective, the potential for boundary spanning activities by store managers to enhance the management of customer experience within the shopping centre has been highlighted (Alexander et al., 2016). 
Figure 1: Relationships within and between retail and service networks in urban places

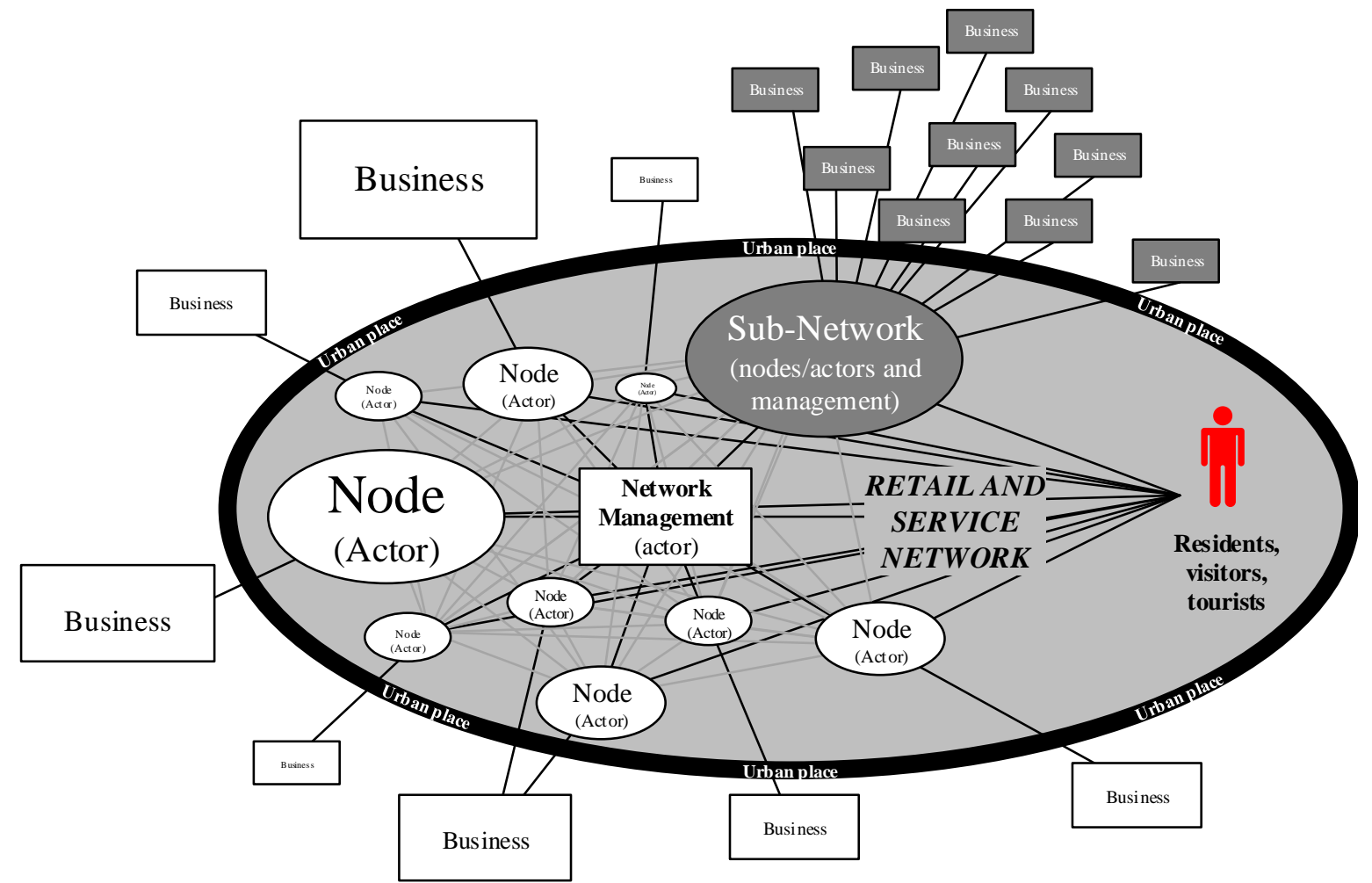

Very little attention has been given to networks within networks in a retail and service context, which is our focus here (for an exception see Tax et al., 2013) - see Figure 1. Nevertheless, some literature suggests that sub-networks, such as markets, can occupy an anchor-store like role within a retail and service network to offer an important augmentation of the "place product" for various place user groups such as residents, visitors and tourists. Among the aspects of this enhancement, increases in town centres footfall are particularly notable with uplifts of 25\% reported in relation to UK markets (Hallsworth et al., 2015), and as such, linked shopping trips provide considerable positive spill-over effects for other stakeholders.

\section{Research propositions}

\subsection{The network-node/sub-network performance interdependency}

Retail trading in markets has economic, social, cultural and environmental effects. Its potential significance as a customer traffic driver has seen markets highlighted in public debate and policy concerned with the sustainability of the town centre as a retail destination (e.g. Watson and Studdert, 2006; Portas, 2011). In terms of economic impact, the existence of a 'multiplier effect' of markets has been quite widely documented (Hallsworth et al., 2015; National Association of British Market Authorities, 2015). More generally, it is suggested that markets are crucial to the distinct identity of a town or area (Hallsworth et al., 2015). 
From a retail and service network point of view, the whole set of service units - to include retail stores and hospitality outlets (henceforth 'store'), wider visitor and tourism services, infrastructural services, and markets - together contribute to a holistic customer experience that increases their attractiveness to customers and enhances the synergetic effect between nodes. Such augmentation affects the performance and the overall value of the urban network, which then spills over to their nodes, including the sub-networks (Swaminathan and Moorman, 2009). That is to say, the performance of a geographically-bounded retail and service network is closely tied to the performance of its nodes and sub-networks. Focusing on the predominantly commercial dimension of the inter-play between nodes and networks, and applying this to the case of markets located in town and city centres, our first proposition is:

$P_{1}$ : There is an interrelationship between the commercial performance of a network and that of its sub-network.

\subsection{The network spill-over effect}

Based on the notions of Teller et al. (2016a) such a network spill-over effect can result in a positive as well as negative outcome for the nodes and the sub-network. For example, issues related to suboptimal infrastructural services such as parking, cleaning, security or ineffective network management can result in a lower attractiveness of the network and subsequent performance of the nodes and sub-network. The notion of a spill-over effect that reflects the close interdependence between the network and its nodes and sub-networks is reflected in the next proposition:

$P_{2}$ : The commercial interrelationship $\left(P_{1}\right)$ between the network and its sub-network generates positive and negative spill-over effects from the network to the sub-network.

\subsection{The sub-network spill-over effect}

Most studies on the antecedents of patronage of geographically-bounded networks, such as shopping centres, find that the retail and service tenant mix has the main impact on attractiveness and performance (for an overview, see Teller and Reutterer, 2008). This clearly indicates the presence of a node spill-over effect and thus suggests stores are a main source of the success of a retail and service network. The contribution of each store to the overall performance of the centre differs between stores. This variation is seen in the unequal power 
of each store within a centre (Finn and Louviere, 1996). For example, key or anchor tenants that consist of notable brands and are of a larger size generate more footfall than the, usually smaller, less well-known organisations that benefit from that footfall rather than attracting customers independently (Teller and Schnedlitz, 2012).

Due to their typical characteristics, including a central location, markets occupy a role similar to an "anchor store" - that is to say they make the whole network more attractive to customers with the potential to increase footfall and ultimately sales. Hallsworth et al. (2015) go beyond the commercial spill-over effect to emphasize the social value of markets for a town or city. Nonetheless, a market can also have negative impacts upon the urban environment - for example those related to increased crowding, potentially leading to increased stress for town/city centre customers. This two-sided view of the nature of spill-over effects reflects the interdependency between sub-network and network and leads to our third proposition:

$P_{3}:$ The commercial interrelationship $\left(P_{1}\right)$ between the network and its sub-network generates positive and negative spill-over effects from the sub-network to the network.

\section{Methodology}

\subsection{Case study design and characterisation}

To test our propositions we applied a multi-method and multi-case study design (Yin, 2011). To attain an in-depth understanding of the reciprocal spill-over effects between a Christmas market and a city centre, our empirical investigations focused on representatives of different levels (stall, store and city centre managers), and included a quantitative (survey) and qualitative (semi-structured interview) research method. In accordance with the recommendations of Yin (2011), the primary research efforts were underpinned by secondary research on the markets and the city centres under scrutiny. This enabled us to understand the empirical research settings and to calibrate the research instruments accordingly. This combination of methods and sources of information allowed us to research the phenomenon from different perspectives and to overcome inherent disadvantages of the applied qualitative and quantitative research methods (Yin, 2012).

In our cases, we focus in particular on the impacts of the augmentation of the urban place product. This process of augmentation alters the attributes of what Hankinson (2004: 115) 
identifies as the core of the place brand. Not only does it provide considerable additional retail provision, but also adds a more distinct leisure/entertainment component to the offer. In other words, it alters the potential functional, symbolic and experiential attributes of the place brand. Based upon this, we then consider the implications for relations between stakeholders of the urban place brand.

The selection of our cases was driven by the opportunity to gain privileged access to two urban areas including Christmas markets. Although both are typical representations of a European Christmas market, they differ in terms of size, catchment and trading history (see Table 1). Case 1 is a comparatively small urban environment with a centrally located and fairly recently established Christmas market. In contrast, Case 2 is a long established and highly successful Christmas market that is within a significantly larger urban environment. The market in Case 2 is also an important tourist attraction and thus has a super-regional catchment.

Both of our market cases are among the larger Christmas markets in their national contexts in terms of size (stall numbers), operate for a significant part of the Christmas season trading period - unlike some others which operate for only a small number of days - and generate significant retail sales. As events that recur annually, they have the potential to become synonymous with the host city centre, and hence make a contribution to its place branding (Jago et al., 2003).

The two urban areas and markets are located in two different European countries. There are differences in terms of the operations of the markets and city centres. That is to say, there is slight variation in aspects such as city/market management, trading regulations, retail and service outlets, and differences in public holidays. However, we do not regard these differences as limiting the investigation of our unit of analysis, which relates to the relationship and effects between city centre and market (Yin, 2012). The market set up is comparable from a commercial point of view and follows the blueprint of a modern Christmas Markets in Germanspeaking countries, in terms of the overall offer, location, and economic relevance. 
Table 1: Case characterisations

\begin{tabular}{|c|c|c|}
\hline Characteristic & Case 1 & Case 2 \\
\hline Urban area population & $\sim 40,000$ & $\sim 131,000$ \\
\hline Date Christmas Market & 2012 & 1973 \\
\hline \multicolumn{3}{|l|}{ Established } \\
\hline Number of stall managers & 103 & 154 \\
\hline Layout & $\begin{array}{l}\text { Concentrated around the } \\
\text { central square }\end{array}$ & $\begin{array}{l}\text { Divided into three connected } \\
\text { sub-markets in and around } \\
\text { the historic city centre }\end{array}$ \\
\hline $\begin{array}{l}\text { Estimated number of } \\
\text { visitors }\end{array}$ & $\sim 175000$ & $\sim 1.3$ million \\
\hline Sales (in Euro) & $\sim 4.1$ million & $\sim 36.5$ million \\
\hline Trading period & $\begin{array}{l}\text { Late November to Mid- } \\
\text { December }\end{array}$ & $\begin{array}{l}\text { Mid-November until the 6th } \\
\text { of January }\end{array}$ \\
\hline Environment & Historic market town & Alpine, historic capital \\
\hline Predominant clientele & Visitors and residents & $\begin{array}{l}\text { Tourists, visitors and } \\
\text { residents }\end{array}$ \\
\hline Catchment & Regional & Super-regional \\
\hline
\end{tabular}

From a methodological perspective, we applied a back-translation procedure between the two languages spoken in the two countries when developing the research instruments - namely the questionnaire and interview guide - and applied the same procedure to the respective direct quotes used in this paper (Behling and Law, 2000). The (back-)translation was facilitated by the fact that the research assistants managing the fieldwork and one member of the author team are bilingual in the relevant languages. In all cases the translation and back-translation was undertaken by a different bilingual research team member in order to ensure linguistic equivalence.

\subsection{Case study investigation approach 1: Surveys}

\subsubsection{Methodology}

\subsubsection{Research design}

To evaluate the relationship between the performance of the market and the performance of the city centre we conducted two surveys. One choosing (deputy) managers of the stalls as respondents and the other one focussing on store managers. By following the notions of Alexander et al. (2016), we regard front line employees with management responsibilities as boundary spanners between their own organisation, the service network (e.g. city centre) and customers. Due to the significant time they spend in and around their workplace within the 
markets and town/city centre, front line managers constitute experts regarding the different measures affecting performance of both the stall/store and the town/city centre.

The research instrument consisted of two questionnaires - the same across the two surveys that were administered by trained research assistants in the market and the stores respectively in each city centre. When structuring the questionnaire and conducting the survey, we followed the tailored design method (TDM) proposed by Dillman et al. (2009). The estimated population for the surveys consisted of managers representing all stalls in the Christmas market (Case 1, 103; Case 2, 154) and stores (Case 1, 313; Case 2, 625) in the city centres under study. The aim was to survey the entire populations of interest. Due to the time pressures that stall and store managers are confronted with during the Christmas period, we managed to secure a sample of 81 stall managers (79\% of the population) and 82 store managers (26\%) in Case 1 and 102 stall managers (66\%) and 103 store managers (17\%) in Case 2. Our samples represent an appropriate representation of the population - namely stalls and stores, in terms of size and sector affiliation.

\subsubsection{Sample characterisation}

\subsection{Case 1}

The market sample included managers representing stalls selling mostly food and beverage specialties (33.0\%), apparel (13.6\%), craft products (11.1\%) and jewellery (11.1\%). All stalls are operated by micro-enterprises; that is to say, those with less than 10 employees. The stalls have an average of 77.9 (standard deviation (s), 97.8) customers per day. $43.2 \%$ of our respondents were both the manager and the owner of the business. The respondents on average have almost four years' experience in the post of manager ( $\mathrm{m}, 3.9, \mathrm{~s}, 5.7)$.

The stores represented by our respondents sell mainly apparel/fashion products (28\%), watches and jewellery etc. (14.6\%) and groceries (8.5\%). The share of micro-enterprises is $31.7 \%$. The average store size is 1,440 square feet $(s, 1076.4)$. Only $7.3 \%$ of the surveyed managers also own the business that operates the store. Our respondents were in their post for an average of 4.6 years $(s, 5.7)$.

\subsection{Case 2}

The surveyed stall managers represent stalls that sell mainly craft products (21.6\%), food and beverage specialties (15.7\%) and mulled wine (13.7\%). 4 out of 5 businesses operating the 
stalls have less than 10 full-time equivalent employees and as such represent micro-enterprises. On average, the stalls have 179 customers per day (s, 253.3). 35.7\% of respondents are both managers of the stall and owner of the business. The respondents on average have more than ten years' experience in the post of manager (m, 10.6, s, 9.6).

The store manager sample represents businesses in the hospitality sector (18.3\%), apparel $(13.5 \%)$ and food (specialty) retail sector $(10.6 \%)$. The share of micro-enterprises is high at $59.6 \%$. The average store size is $2,670.5$ square feet (s, 5384.1). $64.4 \%$ of respondents are managers of the store as well as the owner of the business. The managerial experience of the surveyed store managers is 21.3 years on average (s, 11.7).

\subsubsection{Measurements}

The construct of performance in the context of this study is embedded in the domain of retail management. Consistent with Vyt (2008) and Peteraf and Barney (2003), we consider performance to relate to the effectiveness of creating value relative to the main competitors. Retail performance measures are numerous and their application varies according to the set targets of an organisation (Berman and Evans, 2010). Therefore, due to the absence of a standardised set of measures for retail agglomerations, we follow a frequently applied measurement approach (Vorhies and Morgan, 2005) to distinguish three performance dimensions related outcome measures focusing on customers, the market and the (sub-) network. The applied scale items can be found in the appendix.

To measure each of the three performance dimensions, we followed the approach of Teller et al. (2016a) and slightly amended the scales based on the notions of Vorhies and Morgan (2005) and Pauler et al. (2009). The customer performance dimension - hereafter labelled retail patronage - is of particular importance in a retail and service context. It comprises typical retail patronage (outcome) measures such as satisfaction, loyalty, customer value delivery, meeting customers' needs and customer retention (e.g., Blut et al., 2018). This is consistent with Teller et al. (2016a) as well as Blut et al. (2018) who emphasise that performance of an agglomeration and its stores is closely linked with its effectiveness in creating better value for customers and consequently in establishing a close relationship with customers in terms of patronage.

The market dimension - hereafter labelled market effectiveness - focuses on the development of key marketing success measures of retail and service organisations and agglomerations to 
include sales revenue growth, new customer acquisition, and increases in sales to existing customers (Vorhies and Morgan, 2003; Farris et al., 2010).

The network/sub-network dimension - hereafter labelled operational performance - reflects absolute and widely applied output measures of organisations such as the sales, customer traffic and overall performance (Berman and Evans, 2010; Venkatraman and Ramanujam, 1986). In line with Vorhies and Morgan (2005), the respondents evaluated the performance of the respective markets and the city centres - using the same performance measures - relative to the strongest comparable competitor based on a 7 point bipolar rating scale. The measurement models are depicted in Figure 2. 
Figure 2: Conceptualised performance spill-over effect between the sub-network and the network

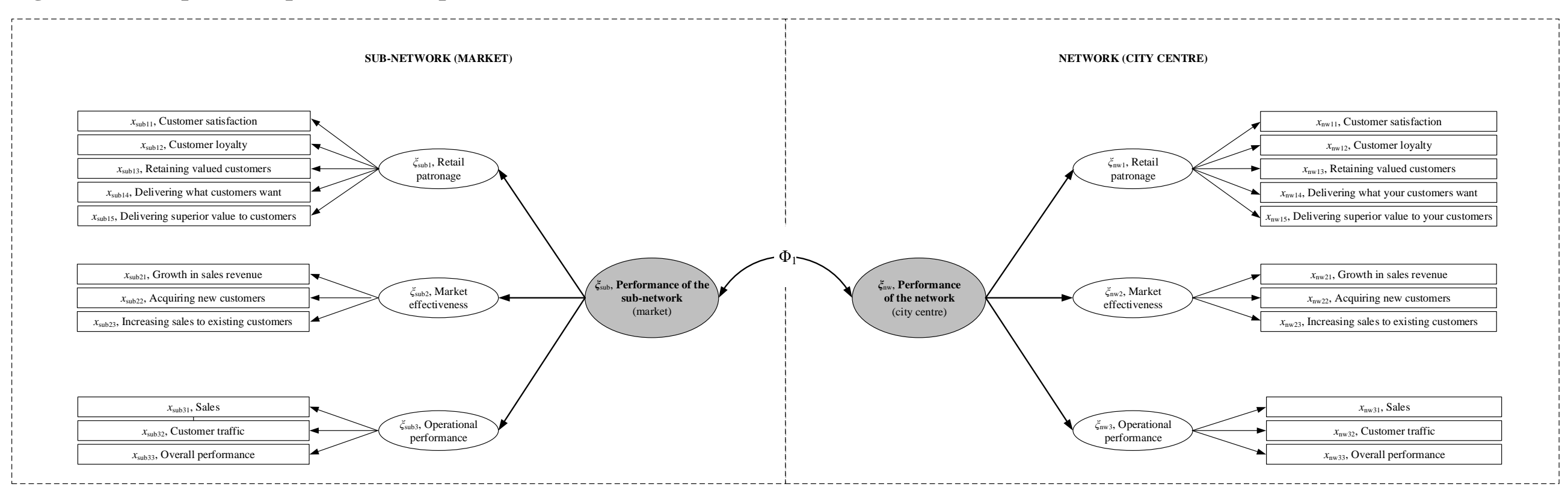

Caption: Questions based on 7 point rating scale, -3 , much worse than main competitor; +3 , much better than main competitor; 


\subsubsection{Results}

\subsubsection{Measurement reliability and validity}

The constructs measuring the three dimensions of performance of the market and the city centre indicated good internal consistencies, with Cronbach alphas $(\alpha)$ above 0.83 (Fornell and Larcker, 1981; see Table 2). To test for measurement validity, we calculated two confirmatory factor analyses, including performance constructs for the market and city centre separately. The data show an acceptably close fit to the model. All fit indices are around or below the recommended thresholds (see caption of Table 2). In both samples, the constructs' composite reliabilities $(\rho>0.60)$ achieved the recommended cut-off criteria (Fornell and Larcker, 1981; see Table 2). In terms of the constructs' discriminant validities, the average variance extracted (AVE), was larger than the highest of the squared inter-correlations with the other factors in the measurement model (Fornell and Larcker, 1981). We conclude that our constructs have a sufficient degree of measurement reliability and validity.

Before exploring proposition one statistically, we collapsed the different dimensions of our scales (variables) to a single item using factor scores. The rationale for this step is to simplify the model and thereby enable a better fit of the limited amount of data available. The reliability measures (Cronbach alphas) of the performance constructs in both samples show very high values -.95 for the construct market performance and .94 for the construct city centre performance. 
Table 2: Convergent validity, composite reliability and discriminant validity

\begin{tabular}{|c|c|c|c|c|c|}
\hline \multicolumn{3}{|l|}{ Case 1/2 } & \multirow[b]{2}{*}{$\xi_{1}$} & \multirow[b]{2}{*}{$\xi_{2}$} & \multirow[b]{2}{*}{$\xi_{3}$} \\
\hline $\begin{array}{l}\text { Performance of the sub-network } \\
\text { (market) }\left(\xi_{\text {sub }}\right)\end{array}$ & $\rho$ & $\alpha$ & & & \\
\hline Retail patronage $\left(\xi_{\text {sub1 }}\right)$ & $.90 / .90$ & $.87 / .86$ & $.81 / .8$ & $.52 / .39$ & $.5 / .4$ \\
\hline Market effectiveness $\left(\xi_{\text {sub2 }}\right)$ & $.91 / .87$ & $.86 / .77$ & $.62 / .44$ & $.88 / 82$ & $.68 / .67$ \\
\hline Operational performance $\left(\xi_{\text {sub3 }}\right)$ & $.93 / .86$ & $.89 / .76$ & $.6 / .45$ & $.77 / .72$ & $.91 / .82$ \\
\hline Fit measures & \multicolumn{5}{|c|}{$\begin{aligned} & \chi^{2}(d f), 237.8(76) ; \mathrm{RMSEA}, .08 ; \mathrm{CFI}, .93 ; \mathrm{TLI} \\
& .90 . ; \text { normed } \chi^{2}(\mathrm{CMIN} / d f), 3.129\end{aligned}$} \\
\hline $\begin{array}{l}\text { Performance of the network (city } \\
\text { centre) }\left(\xi_{\mathrm{nw}}\right)\end{array}$ & $\rho$ & $\alpha$ & $\xi_{1}$ & $\xi_{2}$ & $\xi_{3}$ \\
\hline Retail patronage $\left(\xi_{\mathrm{nw} 1}\right)$ & $.93 / .88$ & $.90 / .84$ & $.85 / .77$ & $.64 / .44$ & $.55 / .43$ \\
\hline Market effectiveness $\left(\xi_{\mathrm{nw} 2}\right)$ & $.90 / .91$ & $.83 / .85$ & $.66 / .47$ & $.86 / .88$ & $.72 / .72$ \\
\hline Operational performance $\left(\xi_{\mathrm{nw} 2}\right)$ & $.90 / .89$ & $.84 / .81$ & $.57 / .46$ & $.75 / .75$ & $.87 / .85$ \\
\hline Fit measures & \multicolumn{5}{|c|}{$\begin{array}{c}\chi^{2}(d f), 226.4(76) ; \text { RMSEA, .07; CFI, .94; TLI, } \\
.91 ; \text { normed } \chi^{2}(\mathrm{CMIN} / d f), 2.97\end{array}$} \\
\hline \multicolumn{6}{|c|}{$\begin{array}{l}\text { Notes: } \rho \text {, composite reliability; } \alpha \text {, Cronbach's alpha; the square roots of the average variance } \\
\text { extracted values (AVE) on the diagonals; the correlation between the latent constructs below the } \\
\text { diagonals; correlations between constructs adjusted for the marker construct above the } \\
\text { diagonals; all correlations (non-adjusted and adjusted) are significant on a } .001 \text { level; cut-off } \\
\text { values for global fit measures: Absolute fit measure: RMSEA (Root Mean Square Error of } \\
\text { Approximation) }<.08 \text {; incremental fit measures: CFI(Comparative Fit Index)/TLI(Tucker-Lewis } \\
\text { Index })>.9 />.9 \text {; parsimony fit measures: Normed } \chi^{2}(\mathrm{CMIN} / d f)<3 \text {; }\end{array}$} \\
\hline
\end{tabular}

\subsubsection{Measurement invariance}

As our analysis is based on samples from two different countries (i.e. Case 1 and Case 2), and different respondent groups (i.e. stall and store managers within each country sample), we tested for measurement invariance in order to ensure that results are comparable. Consequently we evaluated whether there are significant differences (variances) between factor loadings. When comparing the unconstrained measurement model (all parameters are allowed to vary freely across the two groups) and the constrained model (an equality constraint on all factor loading is imposed) we used changes in goodness of fit measures (i.e. the Comparative Fit Index $[\Delta \mathrm{CFI}]$ and the Root Mean Square Error of Approximation [ $\triangle \mathrm{RMSEA}]$ ), as measures of whether non-invariance exists between measurement models. These measures are recommended by Cheung and Rensvold (2002) and Chen (2007) and are deemed to be suitable for small samples and samples of different sizes. The results of the invariance test between the two cases and between the respondent groups within each case reveal that the $\Delta C F I$ values are 
larger than the -.005 and at the same time the $\triangle \mathrm{RMSEA}$ are smaller than .01 in all comparisons. We thus conclude that our measurement models are invariant across the different samples.

\subsubsection{Common method bias}

To consider the potential issues related to a common method bias (CMB) we applied a twostep approach (e.g. Podsakoff et al., 2003; Podsakoff et al., 2012). In the first step, when designing the questionnaire we separated the different questions clearly using introductions and explanations of the question content. Further, the research assistants who administered the questionnaire were trained to guide the respondents through the questionnaire, adapt the pace

of questioning to the respondents' capabilities and provide explanations and repetitions where necessary. Lastly, we used a variety of scales throughout the survey process and did not reveal the aim of our study to the respondents.

In the second step, we tested for CMB. As there is a discussion in the literature on what method to apply and to what extent such a bias impacts data negatively (e.g., Richardson et al., 2009), we applied three different approaches. Firstly we conducted Harman's one-factor tests on our data (Podsakoff and Organ, 1986). In an exploratory factor analysis (EFA) including all variables using unrotated principal component factor analysis, we limited the number of factors to be extracted to one general factor. The results show that the one-factor solution accounted for less than half of the total variance. Secondly, and in line with Podsakoff et al. (2003), a latent method factor (LMF) was introduced in our model that included all indicators under one construct. When comparing the models (with and without LMF) and the results, we found that the factor loadings and path coefficients did not differ substantially in value and were all significant and positive. Lastly, and in line with the notions of Lindell and Whitney (2001), we included a marker construct in our survey. This marker construct, consisting of three variables, is theoretically unrelated to the measures of our conceptual model and evaluates the attitude towards advertising (Barksdale and Darden, 1972). To evaluate the impact of a CMB on our data, we adjusted the correlations between our constructs for the correlation with the marker construct and found that all coefficients remained significant (see Table 2). Based on these three tests, we conclude that $\mathrm{CMB}$ does not have a significant negative effect on results and thus risk compromising our interpretation. 


\subsubsection{Correlation between performance constructs}

To test the relationship between the performance of the markets and the city centres, we conducted confirmatory factor analyses and used the correlation coefficient between the two performance measures to explore proposition one statistically (e.g., Brown, 2006). As we do not assume any pre-determined direction of effects between the two performance measures, we consider the correlation coefficient as the appropriate measure to establish the strength of any relationship between the performance of a market and a town centre (e.g. Churchill and Iacobucci, 2009).

The global fit of the CFA shows an acceptable fit $\left(\chi^{2}(d f), 64.4(32)\right.$; absolute fit measure: RMSEA, .05; incremental fit measures: CFI, .97; TLI, .94; parsimony fit measures: normed $\chi^{2}$ $(\mathrm{CMIN} / d f), 2.03)$. The correlation coefficient for the stall manager sample is .73 (Case 1) and .78 (Case 2) and the store manager sample .73 (Case 1) and .63 (Case 2). In both cases, the coefficients are highly significant $(\mathrm{p}<.001)$. We therefore find support for our first proposition given that there is a close commercial interdependency between the store-based retail and service network and the market with their performances significantly correlated.

Next, we compared the correlation coefficients between the stall and the store manager samples in both cases to determine whether these relationships between the performance constructs are statistically significantly different. Again we conducted an invariance test using $\Delta$ CFI and $\triangle$ RMSEA values to see whether the constrained model (both coefficients are equal) and the unconstrained model (both coefficient vary freely) are different. As all $\Delta C F I$ values are larger than the threshold of -.005 and at the same time the $\triangle$ RMSEA is smaller than .01 we conclude that both the stall and the store manager see the same close relationship in both cases, namely high correlations between the performance of the market and the city centre. Consequently, our proposition one is supported by the different respondent groups in the same way.

\subsection{Case study investigation approach 2: Semi-structured interviews}

\subsubsection{Methodology}

To further explore the relationship between the markets and the city centres, as set out in propositions two and three, we conducted semi-structured interviews with stall and store managers as well as other experts in terms of the respective city centres and markets, such as 
city centre and market managers. The inclusion of different stakeholder groups enabled us to include different perspectives when exploring the phenomenon in greater depth.

Trained research assistants visited the markets and city centres to identify potential interviewees in the target population and to encourage participation in semi-structured interviews. Given the exploratory nature of this study, we drew a purposive judgment sample (e.g. Churchill and Iacobucci, 2009). Thereby, we selected those informants who had an informed and in-depth knowledge related to the markets, the city centres and the relationship between both. Subsequently, in Case 1 we interviewed 8 stall managers/owners, 7 retail store managers/owners of retail businesses in the city centre and two members of the city centre management team who has responsibility for the Christmas market. In Case 2, our interviewees consisted of 6 stall managers/owners, 7 store managers/owners, including the manager of the inner city shopping mall, and six experts affiliated to city centre management initiatives, including two managers of the market under investigation.

To organise the interview stimuli, we developed a semi-structured interview guide consisting of mainly open-ended questions and statements with the aim to stimulate responses and explanations. This process was informed by the literature on agglomeration and spill-over effects in retailing (e.g. Teller et al., 2016a) and that in tourism studies concerned with the relationship between events and the environment in which they are embedded (e.g. Mykletun, 2009). Throughout the interview process, the subjects were encouraged to express their professional and personal views regarding any positive and negative spill-over effects between the city centre and the market.

The qualitative analysis was based on 441 single-spaced A4 pages of transcript and was assisted by inputs from the research assistants who conducted the interviews. First, content analysis was applied to the textual data. This aided the classification of the textual material, reducing it to more relevant, manageable details (Weber, 1990). Our analysis of the data was initially guided by the interview stimuli concerning the positive and negative effects between markets and city centres. Second, we identified distinctive effects within each of those categories. Unlike more interpretative approaches such as thematic text analysis (e.g. Braun and Clarke, 2006) that focus on finding, analysing and describing themes in text data, content analyses provided us with an effective approach to systematically explore and categorise our data. Due to the extent of the textual data, computer-assisted qualitative data analysis software 
QSR NVivo 10 was utilised (Flick, 2009). In order to meaningfully present our results, we introduce direct quotes in the next section.

\subsubsection{Findings}

\subsubsection{A symbiotic relationship between Christmas market and city centre}

Whilst there was some diversity of opinion as to whether the markets benefitted more from the city centres or vice versa, the notion of a symbiotic relationship was identified by both stall managers and the managers of city centre retail outlets. Perhaps unsurprisingly, the managers of stalls in the Christmas market more fully identified the benefits of the Christmas market for the city centre. As the following quotes illustrate, however, this notion of a symbiotic relationship was also shared by some of the store managers we interviewed:

"It is simply an interplay between both [market and city centre] and everyone profits from the other. It is difficult to say who profits from whom. One thing is clear, if the Christmas market would be located on an empty field on the periphery of the city, it would never be as successful as it is in here [the city centre]. At the same time, the centre has a benefit from the market taking place here. Together the whole region benefits. " [Store Manager 6 (Case 2)]

“[F]rom my point of view it seems like it's a 50/50 benefit you know. The town centre will benefit from it just as much as the Christmas market, the stall holders, would. I think if we were not to have a Christmas market we'll definitely feel the effects of it." [Store Manager 4 (Case 1)]

\subsubsection{Positive effects of the market on the city centre}

A wide range of economic (e.g. the generation of employment opportunities, reinvestment of stall rental income) and social benefits (e.g. generation of community spirit, opportunities for social interaction) for city centres deriving from the Christmas markets were identified by respondents to our semi-structured interviews. Our focus here is on the benefits of the markets for city centres in relation to commercial performance - such as competitiveness for resident, visitor and tourist attraction and spend - as well as the implications for the development of the place brand. Nonetheless, we observe an interconnection between these aspects and wider economic and social benefits. 


\subsection{Attraction (increasing footfall)}

There was a clear and widely held view among our interviewees that the Christmas markets were important in generating footfall within the city centre by adding depth and breadth to the retail and service offer during the period in which they operated. This effect in terms of attraction can also be contextualised in relation to the reason for the initial establishment of the Christmas markets - to increase the attractiveness and the performance of the city. Thus, the market is used as a competitive tool that strengthens and differentiates the retail and service network and wider urban environment to benefit the place brand (Hultman et al., 2016). The following quotes are typical of views on the importance of the markets among our respondents:

“... in terms of the kind of, you know, numbers that come into the town, I mean they just would not come like, you know, coach loads, you know 10 coaches one day, 12 coaches the next. Those people wouldn't come and shop here. So I think it benefits everybody. " [Stall Manager 5 (Case 1)]

"Well, for the tourism sector of [name of the city] the market is a major source of income. An income generator tool par excellence. With no other event can you attract that many people to the city. Every bath tub is rented out [as a sleeping place]. There are no more beds available [during the time the market is on]. There is even an effect on the surrounding villages [...] where people rent accommodation." [City Centre Expert 1 (Case 2)]

The perceived benefits in terms of increased footfall from additional tourists and day visitors were complemented by perceived positive effects for local consumers, including city residents. Attention was drawn to how the markets broadened the usual retail and service offer of the city centre and hence the customer experience:

"I think it's added something different [...]. I've lived in the [city name] area for a long time and it's the same old, same old. You don't get often different turnover of shops and things like that, and like I said when something like a Christmas market comes along it's...they're rotating the stalls as well so you get a different product, things that normally people wouldn't like think of doing or exposing themselves to product wise..." [Stall Manager 4 (Case 1)] 
“... a further characteristic [of the market], the social characteristic, a social platform: Christmas markets [...] without entrance fees, [...] no entry restrictions, no dress code [...], ... and becoming increasingly more important as a social meeting point." [Market Manager 1 (Case 2)].

\subsection{Shopping linkages}

The importance of shoppers' linked trips for the sustainability of town/city centre retailing has been explored in relation to a variety of retail development contexts (Lambiri et al., 2017; Wrigley et al., 2019). Thomas and Bromley (2003: 55) suggest that 'it is evident that the closer the degree of spatial integration between the component elements of a shopping centre, the greater the shopping interaction between the parts, and the greater the vitality of the shopping environment.' As the discussion in the literature review suggests, the propensity of markets to generate linked shopping trips and to enhance footfall is important in our cases. The following quotes indicate this:

"I think that [linked trips] does come across from quite a few other people that walk around the market and come in here. New people that, you know, 'oh we haven't been here before' and obviously they are venturing into other shops and spending the day here, so yes it's really good." [Store Manager 6 (Case 1)]

"The Christmas market is certainly a reason why visitors, so tourists and local people, spend more time in the city centre. And if there was no Christmas Market then there would be much less going on especially during the winter." [Store Manager 2 (Case 2)].

\subsubsection{Negative effects of the market on the city centre}

\subsection{Competition for city centre businesses}

Interviewees do acknowledge that there is some overlap between the retail and service offers within the city centre and the market. This leads to a competitive relationship alongside the benefits that the market creates. Similar to Teller et al. (2016a), we thus identify a co-opetitive relationship between the network and the sub-network nodes. Contributions from our interviewees on this issue include the following: 
"I suppose maybe it's a double edged sword in the fact that people might come here [the Christmas market] instead of going to the high street [...] they might come here instead because some of the things are cheaper and you can pick up some novelty things that you can't pick up anywhere else, so that might have a detrimental effect on the town centre itself... so yes, I mean that would be the town being negatively affected and the businesses in the town, especially the small businesses." [Stall Manager 1 (Case 1)]

"People that are close to the Christmas market I think may increase their sales, but the town further away from the market I think will go quiet. I don't think there'll be as much footfall because even the local people go 'oh this is not here very long, let's go to the Christmas market. '..." [Store Manager 7 (Case 1)]

"...there are businesses that do not profit that much, those not being located near [names street names where the markets are]. Yes, it is difficult to say. It is probably those that are not in sight [of the market] that are less interesting [for customers] and less frequented." [Shopping Centre Manager (Case 2)]

\subsection{Collateral damage of the market}

Our informants mentioned other negative spill-over effects of the market that are caused by increased footfall and thus the pressure on infrastructural services of the city. The most frequently mentioned problems related to increased littering, pressures on parking and general congestion. As the following quotes reveal, several place user groups were identified as being affected by congestion, including city centre shoppers, residents, and also businesses through disruptions to the supply of retail stores.

"The negative effects? Probably from the customer feedback it's probably parking and transportation around the city and that's not just the Christmas market that's all year round, but as you can imagine when the Christmas market is there like I said." [Store Manager 4 (Case 1)]

"At the weekends it is massive; it becomes pretty packed at the Christmas market. But this has pros and cons. The tourists have no issue with this. For certain locals this means 'not going there as too many people there.'”' [Stall Manager 5 (Case 2)] 
“... for us it's a little bit of a nightmare because of the way the ...we have trouble with for instance the lorries getting deliveries in because they corner off all of the loading bays to unload coaches so our deliveries have trouble coming in." [Store Manager 5 (Case 1)]

\subsubsection{Positive effects of the city centre on the market}

We structured our exploration of these possible positive (and negative) spill-over effects to reflect the multi-faceted nature of town and city centres as places.

\subsection{Urban embeddedness of the market}

The catchment area of the city centres and their retail and service businesses were seen to benefit the operation of the Christmas markets. This is illustrated by the following quotes:

"I think the size of it. I mean it's [the city] already a tourist attraction, so that's why we're here in the first place. You put a Christmas market in a not so busy town it never works, so we're here because [city name] as a tourist attraction and as a local little economy works very well, so that's why it has worked here for 4 years." [Stall Manager 3 (Case 1)]

"Of course the Christmas market benefits from the footfall of the city centre which can result from a range of things, from the range of service businesses, the city itself and the rest of the retail stores. I mean, the Christmas markets profit also from the [names two inner city shopping malls], as well as the other way round." [Store Manager 5 (Case 2)]

\subsection{Urban design and architecture}

Whilst in Case 1 the morphology of the city centre was identified as restricting opportunities to integrate the Christmas market with some parts of the urban core, the benefits of the overall urban design, for example in terms of good road accessibility to the market site, were acknowledged. In Case 2, the market is located within the city centre with a network of pathways that run between its elements. 
The potential for the architectural forms (and associated symbolic meanings) within the city centres to positively spill over into the operation of the Christmas market was also identified by some of our interviewees. Contributions included:

“... well it's a beautiful setting. I mean God there's hardly any places as fantastic visually as [city name], the market square is really kind of stunning, the [...] square is particularly beautiful. It's great once the sun has gone down and the lights are up so it's just, you know, it really adds a focus to the town, to the city that otherwise wouldn't be here." [Stall Manager 5 (Case 1)]

"There is plenty of history in [city name] but I would imagine most people would think of that as being related to the cathedral and the buildings in and around the cathedral [...] so they will draw people ...” [Store Manager 1 (Case 1)]

"The natural scenery, I think, is a big win, this authentic city centre, the historic surroundings, but also all the contrasts. Well, you have this historic centre in the old part of the city, you have the urban maybe at [name of historic street]. You also have the alpine at the market place with the scenery of the [name of mountain range]. So, that is multi-faceted.” [Store Manager 3 (Case 2)]

\subsubsection{Negative effects of the city centre on the market \\ 4.3.2.5.1 Infrastructural deficiencies}

In particular, stall managers identify issues with the suitability of infrastructural services in the city and the pressures on these services leading to negative effects for the market. This is most notable with regard to infrastructure for motor traffic, including parking, although in the case of the larger city it also extends to orientation of pedestrian traffic.

“I suspect it's more a question of access to parking. There are car parks but they're not generally central, particularly central. You have to walk a little way. Which I guess is fine if you can do that, but perhaps not so good for disabled people." [Store Manager 1 (Case 1)] 
"The parking space issue [...], if I look at it outside the Christmas period, it is used to capacity already, whereas I think that during the Christmas time this is used even more. ...” [Stall Manager 1 (Case 2)]

"From my point of view what I have demanded several times, what the city has not really pursued, is an orientation system and visitor guidance. This would have great potential. Whether from the train station or the city centres [...] or from the car parks. We have suggested that several times. " [Stall Manager 6 (Case 2)]

\subsection{Undesirable behaviour}

Another negative spill-over relates to anti-social behaviour of some consumers of the urban place. For example, one stall manager explained:

"No more so than in any other town [...] maybe a Friday, Saturday night when you've got drunken revellers coming through and, you know, maybe kind of like hanging around and causing a bit of aggro [aggravation] in the Christmas market area, but you know that's life. That's going to happen wherever you are, whatever you do." [Stall Manager 5 (Case 1)]

The occasionally aggressive behaviour of street beggars was identified as being problematic in Case 2, reflecting another negative consequence of the success of the market as a magnet for tourists, visitors and locals.

“Well, this year I have noticed it, in contrast to last year's Christmas market that was significant. They [beggars] ran after people, they nick the mugs [customers have to pay a deposit for them] from the people, they do not leave them in peace [...]. [...] they are in the middle of the crowded streets and just lay down to sleep, whether this is in front of the stores or the fountain [...] I think this is not a nice sight for the visitors." [Store Manager 1 (Case 2)]

We conclude that the findings from the analyses of the semi-structured interviews provide support for research propositions two and three. 


\section{Discussion and conclusions}

\subsection{Markets - augmenting the urban place brand}

Our research contributes to the understanding of the multi-dimensional role of markets in town and city centres. Markets such as Christmas markets can alter perceptions of the functional, symbolic and experiential elements of the urban place product. They are clearly not only an addition in the sense of an attraction or anchor store, but serve to strengthen the traditional role of an urban environment - that is to say, they act as a space where people meet and face to face transactions take place ( $c f$. Watson and Studdert, 2006). They represent a stronghold of retailing embedded within an urban locale that supports town and city centres under competitive pressure. Nevertheless, the research findings also highlight that synergies between markets and the urban retail and service network are reciprocal.

Overall, we have identified strong interdependencies between city centres and markets as well as positive and negative spill-over effect between them. Our research thus contributes to the place branding literature in demonstrating the need to understand that an urban place brand is more than the sum of its parts - and that interactions between them contribute to its success in generating competitive advantage. As such, we agree with Rinaldi and Cavicchi (2016) who advocate the identification of territorial resources and the evaluation of them as clusters or networks. More generally, our research identifies the potential of some markets to provide place attributes that can augment a place brand, casting them as distinctive features that enhance competitiveness and promote the evolution of urban places.

\subsection{Spill-over effects for the good and ill of the urban place brand}

For Rinaldi and Cavicchi (2016; 156), 'place branding is rarely under the control of a central authority, it involves multiple stakeholders, often with competing interests'. The character of a place is thus multi-faceted and contestable (Warnaby and Medway, 2013). The findings of our case study research support this view and reveal positive and negative effects between the town/city centre and the market that can impact on a variety of stakeholders. Table 3 provides a concluding overview of the main positive and negative spill-over effects. 
Table 3: Positive and negative spill-over effects between markets and town and city centres

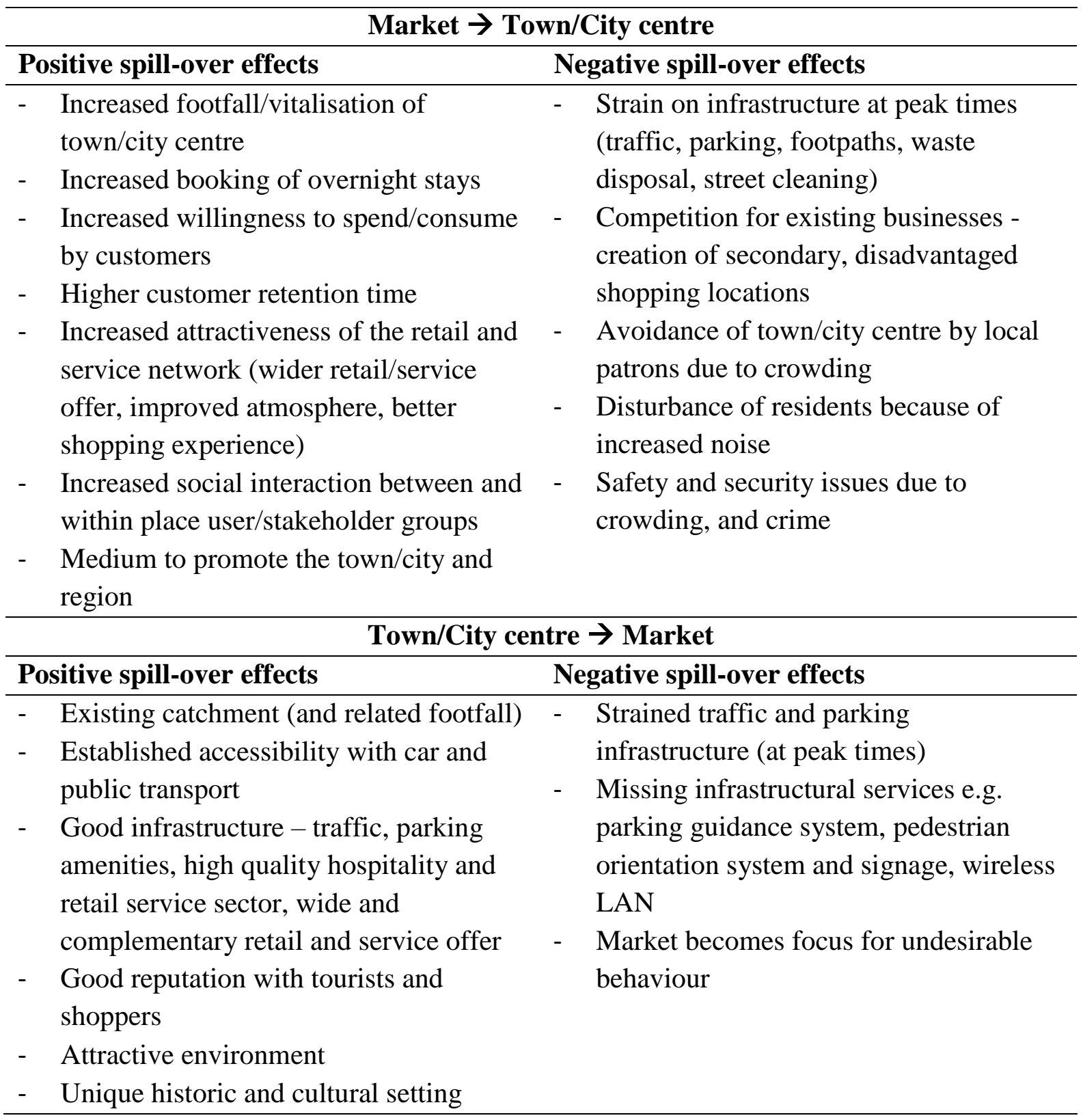

It is apparent from this table that perceptions on the nature of spill-over effects and their impact on experiential attributes may differ among urban place stakeholders. For example, market managers, service providers and visitors might identify the positive impact of the Christmas market in terms of the vitality and vibrancy of the town/city centre (including through opportunities for social interaction). Yet, for some other place users, such as some groups of residents, alternative feelings of being over-crowded and subject to noise disturbance might be the primary experiences during the period the market operates. This serves to highlight the need 
for effective management of the Christmas market, with evaluations of spill-overs addressed from a multi-stakeholder perspective.

\subsection{The market, the town/city centre and the urban place brand network}

Effective management of the interactions between the Christmas market and the existing town/city centre is important for the sustainable development of the place brand. The conceptualisation of space that emerges from the literature underlines that any imposition of a place brand or identity on a locality from the "top down" is likely to be inappropriate (Kavaratzis and Hatch, 2013: 83). Hanna and Rowley (2011), for example, advocate stakeholder engagement and management as 'place brand attributes are not only created and influenced by brand managers ... but are the product of stakeholder networks and partnerships' (p 465).

As such, they require mediation by network and sub-network managers working to develop effective relationships (1) between themselves and (2) with and between the other agents (stakeholders) that represent the diverse nodes making up the place brand network. Hankinson's (2004) categories of place brand relationships can be used to illustrate this point. For example, in relation to primary service relationships, management intervention to promote interactions with and between retail, leisure and hospitality providers are required to maximise the potential benefits accruing during the period of Christmas market trading. At the same time, they need to work to minimise the negative impacts of competition between market and city centre traders. This can occur, for example, through enhanced communication to retail, leisure and hospitality businesses about the operation of the Christmas market and its wider benefits, and also in preventing unnecessary duplication of trade between the market and nearby located businesses in cases where particular sensitivity to such might exist.

Similarly, effective brand infrastructure relationships and consumer relationships are vital in order to identify opportunities for beneficial co-operative endeavour and engagement. They are also necessary in working to lessen or resolve negative spill-overs that may arise, such as parking congestion, over-crowding and noise. Media relationships can be used to advertise and promote understanding (including through public relations) of the Christmas market, with the caveat that, as others have argued, such relationships should be used in the communication of changes in brand reality as they occur (e.g. Hankinson, 2004). 
For the Christmas market to be most effective in augmenting the urban place brand in a sustainable manner, the management of such relationships should be both progressive and include a longer-term perspective (Nordvall, 2016). This would ideally extend from initial consultation with stakeholders prior to implementation through to an ongoing thorough evaluation of the nature and impacts of spill-overs between the market and the town/city centre (Kavaratzis and Hatch, 2013; Warnaby and Medway, 2013). Our research thus contributes to the debate in the place branding literature pertaining to mediating between the interests of different place user groups in relation to the greater benefit of the place brand.

Moreover, whilst the Christmas market itself is intrinsically a seasonal event, its potential contribution in relation to place branding extends beyond this temporality. In particular, the relationships (whether perceived as positive or negative) between key stakeholder groups in the management of the Christmas market event can influence their input to - and evaluation of

- future place branding endeavours; including subsequent Christmas markets. Research in events and tourism management confirms the association between events and place marketing and branding activities (for a review of event tourism research, see Getz and Page, 2016). Jago et al. (2003: 11) report the importance of building an event "beyond time" when discussing the potential legacy effects of events on the destination brand. Such effects can include the development of events management capacity and expertise, and longer term promotional benefits, including effects on the local community's self-perception which, in turn, can influence the place brand or image (Jago et al., 2003). Thus, Christmas markets are clearly worthy of study in relation to place branding beyond the important seasonal augmentation that they can bring to trade.

\section{Limitations and future research}

As with all empirical research, there are limitations with this study which can provide a stimulus for future research. We note these below.

We made a conscious decision on who were the most appropriate informants to use when investigating the relationship between a market and a town/city centre. Our results could be complemented by focusing more directly on other stakeholder groups of markets and town and city centres, such as residents and visitors. 
Both of the markets considered in this research are among the larger Christmas markets in their national contexts. Future research could explore the inter-relationships between town/city centres and markets and the implications for place branding in the case of smaller Christmas markets. Consideration could also be given to those Christmas markets that trade for shorter periods of time during the seasonal period than those analysed here.

Future research on Christmas markets could also usefully undertake a direct analysis of the dynamic relations between the core place brand and the four categories of brand relationship suggested by Hankinson, and of those between the relationship categories themselves (Hankinson, 2004: 115).

We investigated the impact of Christmas markets for two primary reasons. First, their significant importance during the most important period of trade for many retail and service sectors. Second, the characteristics of such markets suggest their significance to the place brand not just in terms of functional inputs, but also in symbolic and experiential terms. Other types of specialty market with similar characteristics but exhibiting a markedly different temporality, for example farmers' markets, might exhibit different impacts on a town or city centre. These could be fruitfully explored in subsequent research.

This research does not attempt cross-country comparisons, for example by contrasting the views of stall managers between the cases. Whilst our research design acknowledged difference in relation to aspects such as trading regulations and public holidays etc., we did not explore the moderating impact of culture on our findings more explicitly. Future research could explore the role of culture, for example, related to market traditions, and the importance of markets in urban communities in detail.

Lastly, the chosen urban retail settings of our cases exist within developed European contexts - exploring the impact of markets in other geographical contexts will provide a wider understanding of their role in the urban environment. 


\section{References}

Alexander, A., Teller, C., \& Roggeveen, A.L. (2016). The boundary spanning of managers within service networks. Journal of Business Research, 69, 6031-6039. https://doi.org/10.1016/j.jbusres.2016.05.018.

Barksdale, H.C., \& Darden, W.R. (1972). Consumer attitudes toward marketing and consumerism. Journal of Marketing, 36, 28-35. https://doi.org/10.1177/002224297203600406.

Behling, O., \& Law, K.S. (2000). Translating questionnaires and other research instruments: Problems and solutions. Thousand Oaks, CA: Sage.

Bell, S.J., Mengüç, B., \& Widing II, R.E. (2010). Salesperson learning, organizational learning, and retail store performance. Journal of the Academy of Marketing Science, 38, 187-201. https://doi.org/10.1007\%2Fs11747-009-0149-x.

Berman, B., \& Evans, J.R. (2010). Retail management. A strategic approach. Upper Saddle River/NJ: Pearson Education.

Blut, M., Teller, C., \& Floh, A. (2018). Testing retail marketing-mix effects on patronage: A meta-analysis. Journal of Retailing, 94, 113-135. https://doi.org/10.1016/j.jretai.2018.03.001.

Braun, V., \& Clarke, V. (2006). Using thematic analysis in psychology. Qualitative Research in Psychology, 3, 77-101. https://doi.org/10.1191/1478088706qp063oa.

Brown, T.A. (2006). Confirmatory factor analysis for applied research. New York, NY: Guildford Press.

Castéran, H., \& Roederer, C. (2013). Does authenticity really affect behavior? The case of the Strasbourg Christmas market. Tourism Management, 36, 153-163. http://doi.org/10.1016/j.tourman.2012.11.012.

Chen, F.F. (2007). Sensitivity of goodness of fit indexes to lack of measurement invariance. Structural Equation Modeling: A Multidisciplinary Journal, 14, 464-504. http://doi.org/10.1080/10705510701301834.

Cheung, G.W., \& Rensvold, R.B. (2002). Evaluating goodness-of-fit indexes for testing measurement invariance. Structural Equation Modeling: A Multidisciplinary Journal, 9, 233-255. http://doi.org/10.1080/10705510701301834.

Churchill, G.A., \& Iacobucci, D. (2009). Marketing research. Methodological foundation. Mason: Thomson - South Western. 
Cresswell, T., \& Hoskins, G. (2008). Place, persistence, and practice: Evaluating historical significance at Angel Island, San Francisco, and Maxwell Street, Chicago. Annals of the Association of American Geographers, 98, 392-413. http://doi.org/10.1080/00045600701879409.

Dillman, D.A., Smyth, J.D., \& Christian, L.M. (2009). Internet, mail, and mixed-mode surveys: The tailored design method. Hoboken, NJ: John Wiley and Son.

Farris, P.W., Bendle, N.T., Pfeifer, P.E., \& Reibstein, D.J. (2010). Marketing metrics. The definition guide to measuring marketing performance. Upper Saddle River (NJ): Prentice Hall.

Finn, A., \& Louviere, J.J. (1996). Shopping center image, consideration, and choice: Anchor store contribution. Journal of Business Research, 35, 241-251. https://doi.org/10.1016/0148-2963(95)00129-8.

Flick, U. (2009). An introduction to qualitative research. London/Thousand Oaks (CA): Sage.

Fornell, C., \& Larcker, D.F. (1981). Evaluating structural equation models with unobservable variables and measurement error. Journal of Marketing Research, 18, 39-40. https://doi.org/10.2307/3151312.

Getz, D., \& Page, S.J. (2016). Progress and prospects for event tourism research. Progress in Tourism Management, 52, 593-631. https://doi.org/10.1016/j.tourman.2015.03.007.

Haid, O. (2006). Christmas markets in the Tyrolean Alps: Representing regional traditions in a newly created world of Christmas. In D. Picard, \& M. Robinson (Eds.), Festivals, Tourism and Social Change: Remaking Worlds (pp. 209-221). Clevedon: Channel view publications.

Hallsworth, A., Ntounis, N., Parker, C., \& Quin, S. (2015). Markets matter. Reviewing the evidence and detecting the market effect. Manchester: The Institute of Place Management.

Hankinson, G. (2004). Relational network brands: Towards a conceptual model of place brands. Journal of Vacation Marketing, 10, 109-121. https://doi.org/10.1177/135676670401000202.

Hankinson, G. (2015). Rethinking the place branding construct. In M. Kavaratzis, G. Warnaby \& G. Ashworth (Eds.), Rethinking Place Branding (pp. 13-31). Cham: Springer International Publishing. 
Hanna, S., \& Rowley, J. (2011). Towards a strategic place brand-management model. Journal of Marketing Management, 27, 458-476. https://doi.org/10.1080/02672571003683797.

Hart, C., Stachow, G., \& Cadogan, J.W. (2013). Conceptualising town centre image and the customer experience. Journal of Marketing Management, 29, 1753-1781. https://doi.org/10.1080/0267257X.2013.800900.

Hospers, G. (2006). Borders, bridges and branding: The transformation of the Øresund region into an imagined space. European Planning Studies, 14, 1015-1033. https://doi.org/10.1080/09654310600852340.

Hultman, M., Yeboah-Banin, A., \& Formaniuk, L. (2016). Demand- and supply-side perspectives of city branding: A qualitative investigation. Journal of Business Research, 69, 5153-5157. https://doi.org/10.1016/j.jbusres.2016.04.096.

Jago, L., Chalip, L., Brown, G., Mules, T., \& Ali, S. (2003). Building events into destination branding: Insights from experts. Event Management, 8, 3-14. https://doi.org/10.3727/152599503108751658.

Jones, C., \& Livingstone, N. (2018). The 'online high street' or the high street online? The implications for the urban retail hierarchy. The International Review of Retail, Distribution and Consumer Research, 28, 47-63. https://doi.org/10.1080/09593969.2017.1393441.

Kavaratzis, M., \& Hatch, M.J. (2013). The dynamics of place brands: An identity-based approach to place branding theory. Marketing Theory, 13, 69-86. https://doi.org/10.1177/1470593112467268.

Kavaratzis, M., \& Kalandides, A. (2015). Rethinking the place brand: The interactive formation of place brands and the role of participatory place branding. Environment and Planning A, 47, 1368-1382. https://doi.org/10.1177/0308518X15594918.

Lambiri, D., Faggian, A., \& Wrigley, N. (2017). Linked-trip effects of 'town-centre-first' era foodstore development: An assessment using difference-in-differences. Environment and Planning B: Urban Analytics and City Science, 44, 160-179. https://doi.org/10.1177/0265813515624684.

Lindell, M.K., \& Whitney, D.J. (2001). Accounting for common method variance in crosssectional research designs. Journal of Applied Psychology, 86, 114-121. http://dx.doi.org/10.1037/0021-9010.86.1.114.

Lucarelli, A., \& Berg, P.O. (2011). City branding: A state-of-the-art review of the research domain. Journal of Place Management and Development, 4, 9-27. https://doi.org/10.1108/17538331111117133. 
Möller, K., \& Rajala, A. (2007). Rise of strategic nets - new modes of value creation. Industrial Marketing Management, 36, 895-908.

https://doi.org/10.1016/j.indmarman.2007.05.016.

Mykletun, R.J. (2009). Celebration of extreme playfulness: Ekstremsportveko at Voss. Scandinavian Journal of Hospitality and Tourism, 9, 146-176. https://doi.org/10.1080/15022250903119512.

National Association of British Market Authorities. (2015). Christmas markets - bringing markets alive for new supporters National Association of British Market Authorities.

Nordvall, A. (2016). Organizing periodic events: A case study of a failed Christmas market. Scandinavian Journal of Hospitality and Tourism, 16, 442-460. https://doi.org/10.1080/15022250.2015.1113142.

Oppewal, H., \& Holyoake, B. (2004). Bundling and retail agglomeration effects on shopping behavior. Journal of Retailing and Consumer Services, 11, 61-74. https://doi.org/10.1016/S0969-6989(02)00079-6.

Pauler, G., Trivedi, M., \& Gauri, D.K. (2009). Assessing store performance models. European Journal of Operational Research, 197, 349-359. https://doi.org/10.1016/j.ejor.2008.05.023.

Peteraf, M.A., \& Barney, J.B. (2003). Unraveling the resource-based tangle. Managerial and Decision Economics, 24, 309-323. https://doi.org/10.1002/mde.1126.

Podsakoff, P.M., MacKenzie, S.B., Jeong-Yeon Lee, \& Podsakoff, N.P. (2003). Common method biases in behavioral research: A critical review of the literature and recommended remedies. Journal of Applied Psychology, 88, 879-903. http://dx.doi.org/10.1037/0021-9010.88.5.879.

Podsakoff, P.M., MacKenzie, S.B., \& Podsakoff, N.P. (2012). Sources of method bias in social science research and recommendations on how to control it. Annual Review of Psychology, 63, 539-569. https://doi.org/10.1146/annurev-psych-120710-100452.

Podsakoff, P.M., \& Organ, D.W. (1986). Self-reports in organizational research: Problems and prospects. Journal of Management, 12, 531-544. https://doi.org/10.1177/014920638601200408.

Portas, M. (2011). The Portas Review. An independent review into the future of our high streets'. Available at www.maryportas.com/, accessed February $8^{\text {th }} 2019$.

Powe, N., \& Hart, T. (2008). Market towns: Understanding and maintaining functionality. The Town Planning Review, 79, 347-370. https://doi.org/10.3828/tpr.79.4.2. 
Richardson, H.A., Simmering, M.J., \& Sturman, M.C. (2009). A tale of three perspectives: Examining post hoc statistical techniques for detection and correction of common method variance. Organizational Research Methods, 12, 762-800. https://doi.org/10.1177/1094428109332834.

Rinaldi, C., \& Cavicchi, A. (2016). Cooperative behaviour and place branding: A longitudinal case study in Italy. Qualitative Market Research: An International Journal, 19, 156-172. https://doi.org/10.1108/QMR-02-2016-0012.

Statista. (2014). Number of Christmas markets worldwide 2014. Available at www.statista.com, accessed February $8^{\text {th }} 2019$.

Swaminathan, V., \& Moorman, C. (2009). Marketing alliances, firm networks, and firm value creation. Journal of Marketing, 73, 52-69. https://doi.org/10.1509/jmkg.73.5.52.

Tax, S.S., McCutcheon, D., \& Wilkinson, I.F. (2013). The service delivery network (SDN): A customer-centric perspective of the customer journey. Journal of Service Research, 16, 454-470. https://doi.org/10.1177/1094670513481108.

Teller, C., Alexander, A., \& Floh, A. (2016a). The impact of competition and cooperation on the performance of a retail agglomeration and its stores. Industrial Marketing Management, 52, 6-17. http://dx.doi.org/10.1016/j.indmarman.2015.07.010.

Teller, C., \& Reutterer, T. (2008). The evolving concept of retail attractiveness: What makes retail agglomerations attractive when customers shop at them? Journal of Retailing and Consumer Services, 15, 127-143. http://dx.doi.org/10.1016/j.jretconser.2007.03.003.

Teller, C., \& Schnedlitz, P. (2012). Drivers of agglomeration effects in retailing: The shopping mall tenant's perspective. Journal of Marketing Management, 28, 1043-1061. http://dx.doi.org/10.1080/0267257X.2011.617708.

Teller, C., Wood, S., \& Floh, A. (2016b). Adaptive resilience and the competition between retail and service agglomeration formats: An international perspective. Journal of Marketing Management, 32, 1537-1561. https://doi.org/10.1080/0267257X.2016.1240705.

Therkelsen, A., Halkier, H., \& Jensen, O.B. (2010). Branding aalborg: Building community or selling place? In G. Ashworth, \& M. Kavaratzis (Eds.), Towards Effective Place Brand Management. Branding European Cities and Regions (pp. 136-155). Cheltenham: Edward Elgar Publishing.

Thomas, C.J., \& Bromley, R.D.F. (2003). Retail revitalization and small town centres: The contribution of shopping linkages. Applied Geography, 23, 47-71. http://dx.doi.org/10.1016/S0143-6228(02)00068-1. 
Venkatraman, N., \& Ramanujam, V. (1986). Measurement of business performance in strategy research: A comparison of approaches. Academy of Management Review, 11, 801-814. https://doi.org/10.5465/amr.1986.4283976.

Vorhies, D.W., \& Morgan, N.A. (2003). A configuration theory assessment of marketing organization fit with business strategy and its relationship with marketing performance. Journal of Marketing, 67, 100-115. https://doi.org/0.1509/jmkg.67.1.100.18588.

Vorhies, D.W., \& Morgan, N.A. (2005). Benchmarking marketing capabilities for sustainable competitive advantage. Journal of Marketing, 69, 80-94. https://doi.org/10.1509/jmkg.67.1.100.18588.

Vyt, D. (2008). Retail network performance evaluation: A DEA approach considering retailers' geomarketing. The International Review of Retail, Distribution and Consumer Research, 18, 235-253. https://doi.org/10.1080/09593960701868522.

Warnaby, G. (2013). Synchronising retail and space: Using urban squares for competitive place differentiation. Consumption, Markets \& Culture, 16, 25-44. https://doi.org/10.1080/10253866.2011.652825.

Warnaby, G., \& Medway, D. (2013). What about the 'place' in place marketing? Marketing Theory, 13, 345-363. https://doi.org/10.1177/1470593113492992.

Watson, S., \& Studdert, D. (2006). Markets as sites for social interaction spaces of diversity. Bristol: Joseph Rowntree Foundation.

Weber, R.P. (1990). Basic content analysis. Newbury Park: Sage.

Wrigley, N., \& Lambiri, D. (2014). High street performance and evolution: A brief guide to the evidence. Southampton, UK: University of Southampton.

Wrigley, N., Wood, S., Lambiri, D., \& Lowe, M. (2019). Corporate convenience store development effects in small towns: Convenience culture during economic and digital storms. Environment and Planning A: Environment and Planning A: Economy and Space. 51, 112-132. https://doi.org/10.1177/0308518X18796507.

Yin, R.K. (2011). Case study research: Design and methods. London: Sage.

Yin, R.K. (2012). Applications of case study research. Thousand Oaks: Sage.

Zenker, S. (2011). How to catch a city? The concept and measurement of place brands. Journal of Place Management and Development, 4, 40-52. https://doi.org/10.1108/17538331111117151. 


\section{Appendix: Applied scales}

\begin{tabular}{|c|c|c|c|}
\hline \multicolumn{2}{|l|}{$\begin{array}{l}\text { Construct } \\
\text { Indicator }\end{array}$} & Construct & \\
\hline \multicolumn{2}{|c|}{$\xi_{\text {sub }}$, Performance of the sub-network (market) ${ }^{*}$} & \multicolumn{2}{|c|}{$\begin{array}{l}\text { Indicator } \\
\xi_{\mathrm{nw}}, \text { Performance of the network (city centre) }{ }^{*}\end{array}$} \\
\hline \multicolumn{2}{|c|}{$\xi_{\text {subl }}$, Patronage related to the sub-network (market) ${ }^{* *}$} & \multicolumn{2}{|c|}{$\xi_{\mathrm{nw} 1}$, Patronage related to the network (city centre) ${ }^{* *}$} \\
\hline $\begin{array}{l}\text { Customer } \\
\text { dimension }\end{array}$ & $\begin{array}{l}x_{\text {sub11 }}, \text { Customer satisfaction } \\
x_{\text {sub12 }}, \text { Customer loyalty } \\
x_{\text {sub13 }}, \text { Retaining valued customers } \\
x_{\text {sub14 }} \text {, Delivering what customers want } \\
x_{\text {sub15, Delivering superior value to customers }}\end{array}$ & $\begin{array}{l}\text { Customer } \\
\text { dimension }\end{array}$ & $\begin{array}{l}x_{\mathrm{nw11}}, \text { Customer satisfaction } \\
x_{\mathrm{nw1} 2} \text {, Customer loyalty } \\
x_{\mathrm{nw1} 13} \text {, Retaining valued customers } \\
x_{\mathrm{nw1}}, \text { Delivering what customers want } \\
x_{\mathrm{nw15}}, \text { Delivering superior value to customers }\end{array}$ \\
\hline \multicolumn{2}{|c|}{$\xi_{\mathrm{sub} 2}$, Market effectiveness of the sub-network (market) ${ }^{* *}$} & \multicolumn{2}{|c|}{$\xi_{\mathrm{nw} 2}$, Market effectiveness of the network (city centre) ${ }^{* *}$} \\
\hline $\begin{array}{l}\text { Market } \\
\text { dimension }\end{array}$ & $\begin{array}{l}x_{\text {sub21 }}, \text { Growth in sales revenue } \\
x_{\text {sub22, Acquiring new customers }} \\
x_{\text {sub23 }} \text { Increasing sales to existing customers }\end{array}$ & $\begin{array}{l}\text { Market } \\
\text { dimension }\end{array}$ & $\begin{array}{l}x_{\mathrm{nw} 21}, \text { Growth in sales revenue } \\
x_{\mathrm{nw} 22} \text {, Acquiring new customers } \\
x_{\mathrm{nw} 23} \text {, Increasing sales to existing customers }\end{array}$ \\
\hline \multicolumn{2}{|c|}{$\xi_{\mathrm{sub} 3}$, Operational performance of the sub-network (market) ${ }^{* *}$} & \multicolumn{2}{|c|}{$\xi_{\mathrm{nw} 3}$, Operational performance of the network (city centre) ${ }^{* *}$} \\
\hline $\begin{array}{l}\text { Sub- } \\
\text { network } \\
\text { dimension }\end{array}$ & $\begin{array}{l}x_{\text {sub31, }} \text { Sales } \\
x_{\text {sub32, }} \text { Customer traffic } \\
x_{\text {sub33, }} \text { Overall performance }\end{array}$ & $\begin{array}{l}\text { Network } \\
\text { dimension }\end{array}$ & $\begin{array}{l}x_{\mathrm{nw} 31}, \text { Sales } \\
x_{\mathrm{nw} 32}, \text { Customer traffic } \\
x_{\mathrm{nw} 33}, \text { Overall performance }\end{array}$ \\
\hline $\begin{array}{l}\text { Notes: }{ }^{*}, \mathrm{r} \\
\text { Morgan's } \\
\text { does not } \mathrm{r} \\
\text { al., } 2010 ;\end{array}$ & $\begin{array}{l}\text { 2005) construct label for the first performance dimer } \\
\text { lect all the items comprised in this scale, in particula } \\
\text { lut et al., 2018; } \xi_{\text {nw3 }} / \xi_{\text {sub3 } 3} \text {, Venkatraman and Ramanu }\end{array}$ & $\begin{array}{l}\text { ignificantly } \\
\text { stomer satisf } \\
\text { ustomer valu }\end{array}$ & $\begin{array}{l}\text { er than the strongest competing network (city centre); Vorhies and } \\
\text { on". However this overlaps with the label of the first indictor and } \\
\text { ources: } \xi_{\text {sub1 }} / \xi_{\text {nw1 }} \text { and } \xi_{\text {sub2 }} / \xi_{\text {nw2 } 2} \text {, Vorhies and Morgan, } 2005 \text {, Bell et } \\
\text { al., } 2010 \text {; }\end{array}$ \\
\hline
\end{tabular}

